\title{
Water Quality of the Trstionica River (Bosnia and Herzegovina)
}

\author{
Š. Delibašić, J. Huremović, ${ }^{*}$ S. Žero, and S. Gojak-Salimović \\ University of Sarajevo, Faculty of Science, Zmaja od Bosne 33-35, 71000 Sarajevo, \\ Bosnia and Herzegovina
}

\begin{abstract}
The present study was conducted to investigate the water quality of the Trstionica River, Bosnia and Herzegovina. The physicochemical properties (temperature, $\mathrm{pH}$, conductivity, total solids after evaporation at $105{ }^{\circ} \mathrm{C}$ ), content of metals (calcium $(\mathrm{Ca})$, cadmium $(\mathrm{Cd})$, chromium $(\mathrm{Cr})$, copper $(\mathrm{Cu})$, iron $(\mathrm{Fe})$, magnesium $(\mathrm{Mg})$, manganese $(\mathrm{Mn})$, sodium $(\mathrm{Na})$, nickel $(\mathrm{Ni})$, lead $(\mathrm{Pb})$ and zinc $(\mathrm{Zn})$ ), and anions (chloride $\left(\mathrm{Cl}^{-}\right)$, and phosphate $\left(\mathrm{PO}_{4}{ }^{3-}\right)$ ) were determined in water samples collected at seven locations during two sampling periods: unstable weather conditions (precipitation), and stable weather conditions (without precipitation). There was a significant difference in the content of individual parameters in the river water depending on the sampling time. For determination of metals concentrations, which were below the limit of detection, a preconcentration method using an ion-exchange resin was applied. The metals concentrations during the rainy day were in the order $\mathrm{Ca}>\mathrm{Mg}>\mathrm{Na}>\mathrm{Fe}>\mathrm{Cu}>\mathrm{Zn}>\mathrm{Pb}>\mathrm{Mn}$ with mean values of 343, 6.03, 1.94, 0.18, 0.20, 0.03, 0.02, $0.01 \mathrm{mg} \mathrm{dm}^{-3}$, respectively, and during stable weather conditions: $\mathrm{Ca}>\mathrm{Mg}>\mathrm{Na}>\mathrm{Cu}>\mathrm{Fe}>\mathrm{Mn}>\mathrm{Zn}$ with mean values of 288, 7.62, 2.38, 0.11, $0.10,0.01,0.01 \mathrm{mg} \mathrm{dm}^{-3}$, respectively. $\mathrm{Cd}, \mathrm{Cr}$, and $\mathrm{Ni}$ concentrations were below limit of detection in both cases.

Obtained values were compared with World Health Organization (WHO) regulations. The results showed that the Trstionica River in the investigated part of the stream meets most of the parameters required by the regulations. The correlation between analysed parameters was assessed, as well. Based on the calculated water quality index values, the water of Trstionica River falls into the category of excellent water.
\end{abstract}

\section{Keywords}

Trstionica River, pollution, metals, AAS, chlorides, phosphates, preconcentration

\section{Introduction}

Water is one of the most important substances for life on Earth, and its quality is of great importance to human health. It is an important source of trace elements for the proper functioning of the human organism. ${ }^{1,2}$ There are many sources of water pollution, but the main sources are pollution from industrial and municipal wastewater discharges, inputs from agricultural activities that include the use of chemicals and fertilizers, seepage from waste sites, decaying plant life, etc., all leading to environmental degradation, and the necessity for environmental protection. ${ }^{3,4,5}$ Different classes of contaminants like inorganic substances (toxic metals, salts, and acids), organic compounds (organic solvents, pesticides, fossil fuels, etc.), anions and cations (phosphate, sulphates, nitrates, calcium, magnesium, and fluorine ions), water-soluble radioactive substances, and pathogenic microorganisms (viruses, bacteria, and protozoan) are considered common pollutants of aquatic environments. ${ }^{6}$ As heavy metals cannot be degraded, they are continuously being deposited and incorporated into water, aquatic organisms, and sediment. The persistence and accumulation of many heavy metals produce a significant ecological problem. ${ }^{7,8,9}$

\footnotetext{
${ }^{*}$ Corresponding author: Jasna Huremović, PhD

Email: jasnahuremovic@yahoo.com
}

Trstionica River (Bosnia and Herzegovina) is made up of several smaller streams that spring up on the outskirts of Zvijezda Mountain at about $1100 \mathrm{~m}$ above sea level. The length of the Trstionica River is about $35 \mathrm{~km}$, and the catchment area is $161 \mathrm{~km}^{2}$. In the city of Kakanj it flows into the Bosna River as its right tributary. The river area is predominantly mountainous with a moderate continental climate, and is rich in river flows and drinking water sources, but the river water is not used for drinking purposes. Through its basin, the Trstionica River is exposed to numerous possible sources of pollution that could significantly affect its quality: households (sewers), industry (polyurethane-based products and coal mine), agriculture (all types of pesticides - herbicides, fungicides, etc.), wild landfills (in suburban and rural settlements).

The aim of this study was to analyse Trstionica River water samples by 17 parameters: metal concentrations including $\mathrm{Ca}, \mathrm{Cd}, \mathrm{Cr}, \mathrm{Cu}, \mathrm{Fe}, \mathrm{Mg}, \mathrm{Mn}, \mathrm{Na}, \mathrm{Ni}, \mathrm{Pb}$, and $\mathrm{Zn}$, temperature, $\mathrm{pH}$, conductivity, total solids after evaporation at $105{ }^{\circ} \mathrm{C}$, and anion mass concentration (chlorides and phosphates) at seven locations during two sampling periods: unstable weather conditions (precipitation), and stable weather conditions (without precipitation). In addition, the water quality index (WQI) was calculated. The water quality index represents a large amount of water quality data in simple terms for reporting to decision makers, and the public. It provides a simple and understandable tool for decision makers in obtaining information on water quality and permitting certain uses of water. 


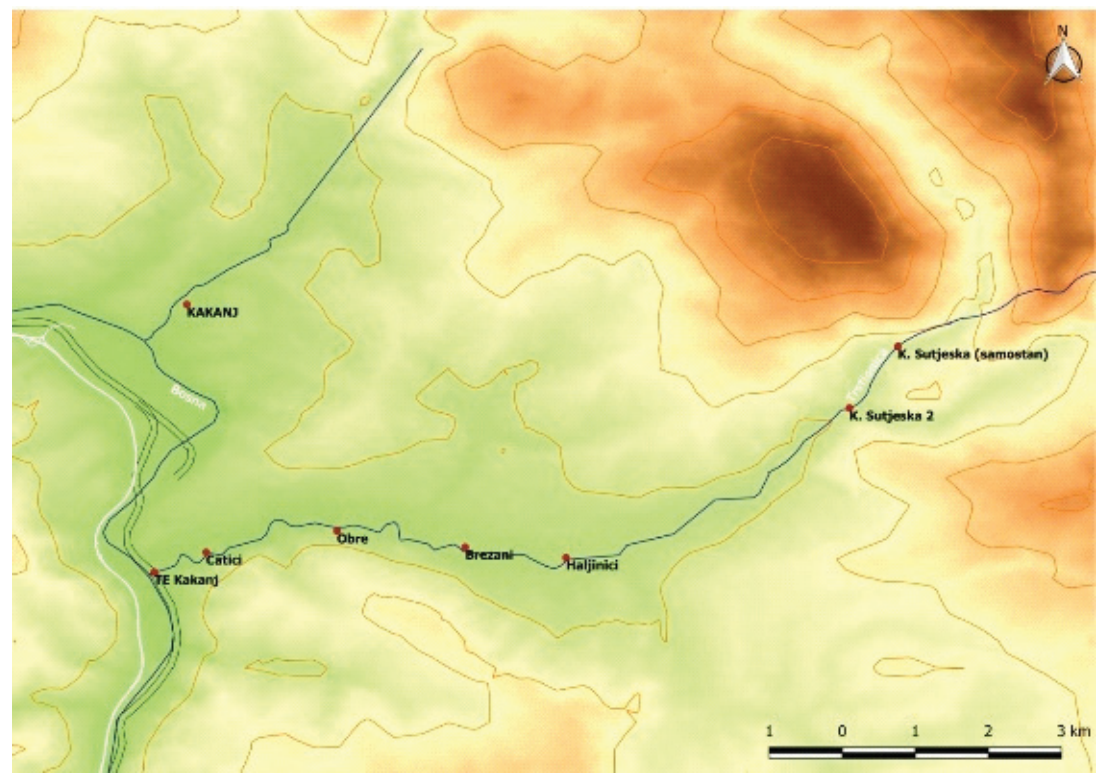

Fig. 1 - Sampling locations

Slika 1 - Lokacije uzorkovanja

\section{Experimental}

\subsection{River water sampling}

The Trstionica River water samples were taken along the river at seven locations (Fig. 1): Thermal Power Plant (TE) Kakanj (a place where the Trstionica River flows into the Bosna River), Čatići, Obre, Brežani, Haljinići, Kraljeva Sutjeska 1 (Trstionica River spring), and Kraljeva Sutjeska 2. Samples were collected in clean polyethylene bottles two meters from the shore and at the depth of $50 \mathrm{~cm}$.

Sampling was carried out along the Trstionica River on two days: day I - November 6, 2016 (unstable weather conditions, very cold, and rainy), and day II - November 25, 2016 (stable weather conditions, sunny, and warmer). After determination of conductivity and $\mathrm{pH}$, the samples were preserved by adding $2 \mathrm{~cm}^{3}$ of $65 \% \mathrm{HNO}_{3}$ to each sample bottle $\left(2 \mathrm{dm}^{3}\right)$. All plastic and glassware used for sampling and analysis were washed with $10 \% \mathrm{HNO}_{3}$ and rinsed with Milli-Q water.

\subsection{Instruments and reagents}

Water samples were analysed by parameters: temperature, $\mathrm{pH}$, conductivity, total solids after evaporation at $105^{\circ} \mathrm{C}$, metal concentrations $(\mathrm{Ca}, \mathrm{Cd}, \mathrm{Cr}, \mathrm{Cu}, \mathrm{Fe}, \mathrm{Mg}, \mathrm{Mn}, \mathrm{Na}, \mathrm{Ni}$, $\mathrm{Pb}$, and $\mathrm{Zn}$ ), chlorides, and phosphates.

Atomic absorption spectrometer (AAS) (AA240FS, Varian, Australia) was used for the determination of metals: flame technique (FAAS) for determination of $\mathrm{Cr}, \mathrm{Cu}, \mathrm{Fe}, \mathrm{Mn}, \mathrm{Ni}$, $\mathrm{Pb}, \mathrm{Zn}, \mathrm{Ca}$, and $\mathrm{Mg}$, and atomic emission spectrometry (AES) (AA240FS, Varian, Australia) for determination of Na. Single-standard stock solutions containing $1000 \mathrm{mgdm}^{-3}$ of the metals analysed (CertPur, Merck, Darmstadt, Germany) were used. Standard solutions were prepared daily by dilutingstock solutions. All reagents used were of analytical grade.
Milli-Q water was used throughout the experimental work. All samples were analysed in triplicate. Comparison of the triplicate results showed significant agreement, confirming the quality of analytical data. The detection limits (LOD) were calculated on the basis of three times the standard deviation of the blank signal. The obtained LOD values for the investigated metals were: Ca $\left(0.001 \mathrm{mg} \mathrm{dm}^{-3}\right)$, $\mathrm{Cd}\left(0.002 \mathrm{mgdm}^{-3}\right), \mathrm{Cr}\left(0.006 \mathrm{mgdm}^{-3}\right), \mathrm{Cu}\left(0.003 \mathrm{mgdm}^{-3}\right)$, Fe $\left(0.006 \mathrm{mg} \mathrm{dm}^{-3}\right), \quad \mathrm{Mg}\left(0.0003 \mathrm{mg} \mathrm{dm}^{-3}\right), \mathrm{Mn}$ $\left(0.002 \mathrm{mgdm}^{-3}\right), \mathrm{Na}\left(0.0002 \mathrm{mgdm}^{-3}\right), \mathrm{Ni}\left(0.01 \mathrm{mgdm}^{-3}\right)$, $\mathrm{Pb}\left(0.01 \mathrm{mg} \mathrm{dm}^{-3}\right)$, and $\mathrm{Zn}\left(0.001 \mathrm{mg} \mathrm{dm}^{-3}\right)$. In the case of metals $\mathrm{Cd}, \mathrm{Cr}, \mathrm{Cu}, \mathrm{Ni}, \mathrm{Pb}$, and $\mathrm{Zn}$, the concentrations were below the limit of detection of the method used (FAAS); therefore, a preconcentration method using an ion-exchange resin (lon Exchanger I, 4.5 $\mathrm{W} \mathrm{g}^{-1}, 45-55 \%$, MERCK (Darmstadt, Germany) was applied. ${ }^{13}$

UV/Vis spectrophotometer (Carry 50, Varian, Australia) was used for phosphates analysis. Chloride content was determined by volumetric method, mercurimetric titration.

Conductivity meter (HANNA Instruments, Model HI 8733, Sigma, Singapore) and pH meter (CG841, Schott, Germany) were used for conductivity and $\mathrm{pH}$ measurements.

The WQI was calculated using the methodology described by Batabyal and Chakraborty. ${ }^{10}$ Nine parameters ( $\mathrm{pH}$, chloride, $\mathrm{Ca}, \mathrm{Cu}, \mathrm{Fe}, \mathrm{Mg}, \mathrm{Mn}, \mathrm{Na}, \mathrm{Zn}$; parameters detected in the water samples for which the water quality index (WQI) allowable value is given) were used for the calculation of the WQI. According to Batabyal and Chakraborty, ${ }^{10}$ the calculated WQI values are classified into five categories: excellent water (WQI < 50); good water $(\mathrm{WQI}=50-100)$; poor water $(\mathrm{WQI}=100-200)$; very poor water (WQI = 200-300); and water unsuitable for drinking (WQI > 300).

Pearson's matrix correlations were used for the analysis of the data for all water parameters. 


\section{Results and discussion}

Physicochemical parameters, chlorides, and phosphates in Trstionica River water samples are given in Table 1.

Water temperatures ranged from 7 to $12^{\circ} \mathrm{C}$ for both sampling days. The lowest value was recorded at the river spring itself (Kraljeva Sutjeska 1). The conductivity depends on the type of ions present in the water, ion concentration, motility, and charge of the ions, as well as on the temperature at which it is determined. ${ }^{11}$ Conductivity decreased as approaching the spring, where the lowest value was determined.

The $\mathrm{pH}$ varied insignificantly, and was in the range from slightly alkaline to alkaline. The $\mathrm{pH}$ values in most of the cases were lower in water samples collected during unstable weather conditions, a very cold and rainy day. In addition, total solids after evaporation at $105^{\circ} \mathrm{C}$ and chlorides concentrations were higher in almost all samples on the day with unstable weather conditions. Almost all natural water contains significant chloride amounts in compounds such as $\mathrm{CaCl}_{2}, \mathrm{MgCl}_{2}, \mathrm{NaCl}$, etc. Most drinking water contains around $30 \mathrm{mg} \mathrm{dm}^{-3}$ of chlorides, and the maximum allowed concentration is $250.00 \mathrm{mg} \mathrm{dm}{ }^{-3} .{ }^{12}$ There was a gradual increase in the chlorides concentration from spring to mouth into the river Bosna.

In most samples, the phosphate content was below the detection limit of the method used. Concentration of $\mathrm{Cd}$, $\mathrm{Cr}$ and $\mathrm{Ni}$, and $\mathrm{Pb}$ during sampling day II was below limits of detection of method applied, so a preconcentration method using an acidic ion-exchange resin was used. The remaining metals were analysed directly from the samples. The mean metals concentrations in Trstionica River water samples are presented in Table 2.

According to WHO (2003), maximum allowed concentrations (MAC) of metals in drinking water are: Ca $\left(200 \mathrm{mg} \mathrm{dm}^{-3}\right), \mathrm{Cd}\left(0.005 \mathrm{mg} \mathrm{dm}^{-3}\right), \mathrm{Cr}\left(0.05 \mathrm{mg} \mathrm{dm}^{-3}\right)$,
$\mathrm{Cu}\left(2.00 \mathrm{mg} \mathrm{dm}^{-3}\right), \mathrm{Fe}\left(0.2 \mathrm{mg} \mathrm{dm}^{-3}\right), \mathrm{Mg}\left(50 \mathrm{mg} \mathrm{dm}^{-3}\right)$, $\mathrm{Mn}\left(0.05 \mathrm{mgdm}^{-3}\right), \mathrm{Na}\left(200 \mathrm{mgdm}^{-3}\right), \mathrm{Pb}\left(0.01 \mathrm{mgdm}^{-3}\right)$, $\mathrm{Zn}\left(5.00 \mathrm{mg} \mathrm{dm}^{-3}\right) .{ }^{12}$ The content of $\mathrm{Cd}, \mathrm{Cu}, \mathrm{Mg}, \mathrm{Mn}, \mathrm{Na}$, and $\mathrm{Zn}$ was below the defined MAC values in all samples. Ca concentration was higher than MAC for drinking water in all river water samples; Fe content was slightly higher than MAC in two samples, while Pb content in three samples collected during the rainy day was above MAC. Similar results were obtained in the Bosna River water quality study..$^{13}$ The Trstionica flows directly into the Bosna River.

Metals in water samples during the rainy day were arranged as the following diminishing series by concentrations: $\mathrm{Ca}>\mathrm{Mg}>\mathrm{Na}>\mathrm{Fe}>\mathrm{Cu}>\mathrm{Zn}>\mathrm{Pb}>\mathrm{Mn}>\mathrm{Cr} \approx \mathrm{Cd} \approx \mathrm{Ni}$, and during stable weather conditions:

$\mathrm{Ca}>\mathrm{Mg}>\mathrm{Na}>\mathrm{Cu}>\mathrm{Fe}>\mathrm{Mn}>\mathrm{Zn}>\mathrm{Pb}>\mathrm{Cr} \approx \mathrm{Cd} \approx \mathrm{Ni}$.

There was a significant difference in the content of individual parameters in river water depending on the sampling time (rainy day and stable weather conditions). Trstionica River flows into the Bosnia River. In the same time period, the water analysis of the Bosna River was conducted ${ }^{13}$, and the results obtained in this paper were compared with these data. Similar results were obtained for almost all analysed parameters.

The WQI values are presented in Table 3. Based on the obtained results, the water of Trstionica River is classified as excellent water. The WQI during the unstable weather conditions ranged from 35.9 to 43.3 , and during the stable weather conditions from 27.2 to 48.7. A decrease in the WQI can be noticed during the stable weather conditions at all sampling locations, except at Haljinići. The concentration of iron is a significant constituent for the higher WQI value at the Haljinići sampling location during the stable period. At the Haljinići sampling location is a factory section of the Kakanj coal mine, which can be a source of different metals in Trstionica River.

Table 1 - Physicochemical parameters, chlorides and phosphates in Trstionica River water samples

Tablica 1 - Fizikalno-kemijski parametri, kloridi i fosfati u uzorcima rijeke Trstionice

\begin{tabular}{|c|c|c|c|c|c|c|c|c|c|c|c|c|}
\hline \multirow[t]{2}{*}{ Location } & \multirow[t]{2}{*}{$\begin{array}{c}\text { GPS } \\
\text { Coordinates }\end{array}$} & \multicolumn{2}{|c|}{$\begin{array}{c}\text { Temperature } \\
/{ }^{\circ} \mathrm{C}\end{array}$} & \multicolumn{2}{|c|}{$\mathrm{pH}$} & \multirow{2}{*}{$\begin{array}{l}\text { Conductivity } \\
\qquad / \mu \mathrm{cm}^{-1} \\
\mathrm{I}\end{array}$} & \multicolumn{2}{|c|}{$\begin{array}{c}\text { Total solids after } \\
\text { evaporation at } 105^{\circ} \mathrm{C} \\
/ \mathrm{mg} \mathrm{dm}^{-3}\end{array}$} & \multicolumn{2}{|c|}{$\begin{array}{l}\text { Chlorides } \\
/ \mathrm{mgdm}^{-3}\end{array}$} & \multicolumn{2}{|c|}{$\begin{array}{l}\text { Phosphates } \\
/ \mathrm{mg} \mathrm{dm}^{-3}\end{array}$} \\
\hline & & 1 & II & I & II & & 1 & II & I & II & 1 & II \\
\hline TE Kakanj & $\begin{array}{l}44^{\circ} 05^{\prime} 13^{\prime \prime} \mathrm{N} \\
18^{\circ} 06^{\prime} 45^{\prime \prime} \mathrm{E}\end{array}$ & 12 & 9 & 8.48 & 7.30 & 330 & 305 & 290 & 108.3 & 93.33 & ${ }^{*} \mathrm{n} . \mathrm{d}$. & 0.01 \\
\hline Čatići & $\begin{array}{c}45^{\circ} 05^{\prime} 38^{\prime \prime} \mathrm{N} \\
18^{\circ} 06^{\prime} 49^{\prime \prime} \mathrm{E}\end{array}$ & 12 & 9 & 7.91 & 7.53 & 369 & 375 & 250 & 93.33 & 78.40 & ${ }^{*}$ n.d. & "n.d. \\
\hline Obre & $\begin{array}{l}44^{\circ} 06^{\prime} 09^{\prime \prime} \mathrm{N} \\
18^{\circ} 08^{\prime} 12^{\prime \prime} \mathrm{E}\end{array}$ & 12 & 9 & 7.74 & 7.60 & 367 & 430 & 270 & 89.60 & 85.86 & ${ }^{*}$ n.d. & 0.006 \\
\hline Brežani & $\begin{array}{c}44^{\circ} 05^{\prime} 45^{\prime \prime} \mathrm{N} \\
18^{\circ} 08^{\prime} 49^{\prime \prime} \mathrm{E}\end{array}$ & 12 & 9 & 8.47 & 7.51 & 306 & 300 & 150 & 67.20 & 108.3 & ${ }^{*}$ n.d. & *n.d. \\
\hline Haljinići & $\begin{array}{l}44^{\circ} 05^{\prime} 56^{\prime \prime} \mathrm{N} \\
18^{\circ} 09^{\prime} 15^{\prime \prime} \mathrm{E}\end{array}$ & 11 & 9 & 8.44 & 7.46 & 310 & 365 & 265 & 74.66 & 78.40 & ${ }^{*}$ n.d. & *n.d. \\
\hline $\begin{array}{l}\text { Kraljeva } \\
\text { Sutjeska } 1\end{array}$ & $\begin{array}{l}44^{\circ} 06^{\prime} 33^{\prime \prime} \mathrm{N} \\
18^{\circ} 11^{\prime} 24^{\prime \prime} \mathrm{E}\end{array}$ & 9 & 7 & 7.35 & 7.62 & 266 & 290 & 135 & 59.73 & 37.33 & ${ }^{*}$ n.d. & *n.d. \\
\hline $\begin{array}{l}\text { Kraljeva } \\
\text { Sutjeska } 2\end{array}$ & $\begin{array}{c}44^{\circ} 07^{\prime} 06^{\prime \prime} \mathrm{N} \\
18^{\circ} 11^{\prime} 56^{\prime \prime} \mathrm{E}\end{array}$ & 9 & 7 & 7.67 & 7.54 & 268 & 225 & 110 & 56.00 & 48.53 & "n.d. & "n.d. \\
\hline
\end{tabular}

*n.d. - not detected; I (sampling date November 6, 2016); II (sampling date November 25, 2016) 
Table 2 - Mean metal concentrations $\left(\mathrm{mg} \mathrm{dm}^{-3}\right)$ in Trstionica River water samples $(n=3)$

Tablica 2 - Srednje vrijednosti koncentracija metala $\left(\mathrm{mg} \mathrm{dm}^{-3}\right)$ u uzorcima rijeke Trstionice $(n=3)$

\begin{tabular}{|c|c|c|c|c|c|c|c|c|c|c|c|c|}
\hline \multirow{2}{*}{$\begin{array}{l}\text { Location/Metals } \\
/ \mathrm{mg} \mathrm{dm}^{-3}\end{array}$} & \multicolumn{2}{|c|}{$\mathrm{Ca}$} & \multicolumn{2}{|c|}{$\mathrm{Cd}$} & \multicolumn{2}{|c|}{$\mathrm{Cr}$} & \multicolumn{2}{|c|}{$\mathrm{Cu}$} & \multicolumn{2}{|c|}{$\mathrm{Fe}$} & \multicolumn{2}{|c|}{$\mathrm{Mg}$} \\
\hline & 1 & II & 1 & II & 1 & II & 1 & II & 1 & II & I & II \\
\hline TE Kakanj & 364 & 380 & ${ }^{*}$ n.d. & "n.d. & "n.d. & "n.d. & 0.61 & 0.06 & 0.17 & 0.04 & 6.42 & 8.12 \\
\hline Čatići & 345 & 237 & ${ }^{*}$ n.d. & *n.d. & *n.d. & *n.d. & 0.08 & 0.08 & 0.14 & 0.07 & 6.59 & 8.29 \\
\hline Obre & 342 & 238 & ${ }^{*}$ n.d. & *n.d. & "n.d. & *n.d. & 0.13 & 0.06 & 0.17 & 0.08 & 6.72 & 8.22 \\
\hline Brežani & 341 & 223 & ${ }^{*}$ n.d. & "n.d. & "n.d. & 0.006 & 0.10 & 0.04 & 0.18 & 0.07 & 5.72 & 7.36 \\
\hline Haljinići & 344 & 350 & ${ }^{*}$ n.d. & *n.d. & *n.d. & *n.d. & 0.26 & 0.34 & 0.18 & 0.26 & 5.77 & 8.55 \\
\hline Kraljeva Sutjeska 1 & 336 & 380 & ${ }^{*}$ n.d. & *n.d. & 0.006 & *n.d. & 0.09 & 0.06 & 0.18 & 0.10 & 5.50 & 6.34 \\
\hline Kraljeva Sutjeska 2 & 332 & 206 & "n.d. & *n.d. & "n.d. & *n.d. & 0.11 & 0.13 & 0.21 & 0.10 & 5.49 & 6.46 \\
\hline \multirow{2}{*}{$\begin{array}{l}\text { Location/Metals } \\
/ \mathrm{mg} \mathrm{dm}^{-3}\end{array}$} & \multicolumn{2}{|c|}{ Mn } & \multicolumn{2}{|c|}{$\mathrm{Na}$} & \multicolumn{2}{|c|}{$\mathrm{Ni}$} & \multicolumn{2}{|c|}{$\mathrm{Pb}$} & \multicolumn{2}{|c|}{$\mathrm{Zn}$} & & \\
\hline & I & II & 1 & II & 1 & II & I & II & 1 & II & & \\
\hline TE Kakanj & 0.004 & "n.d. & 1.92 & 2.08 & *n.d. & *n.d. & 0.02 & *n.d. & 0.07 & 0.006 & & \\
\hline Čatići & 0.006 & 0.01 & 4.48 & 4.62 & ${ }^{*}$ n.d. & *n.d. & 0.01 & ${ }^{*}$ n.d. & 0.03 & 0.004 & & \\
\hline Obre & 0.008 & 0.01 & 4.55 & 2.08 & *n.d. & *n.d. & 0.03 & *n.d. & 0.03 & 0.011 & & \\
\hline Brežani & 0.011 & 0.01 & 0.76 & 2.11 & ${ }^{*}$ n.d. & *n.d. & 0.01 & *n.d. & 0.01 & 0.021 & & \\
\hline Haljinići & 0.010 & 0.02 & 0.88 & 3.51 & "n.d. & *n.d. & 0.02 & *n.d. & *n.d. & *n.d. & & \\
\hline Kraljeva Sutjeska 1 & 0.017 & 0.01 & 0.14 & 1.07 & "n.d. & *n.d. & 0.01 & *n.d. & 0.03 & 0.025 & & \\
\hline Kraljeva Sutjeska 2 & 0.024 & 0.02 & 0.86 & 1.16 & *n.d. & *n.d. & 0.01 & *n.d. & 0.02 & 0.011 & & \\
\hline
\end{tabular}

"n.d. - not detected; I (sampling date November 6, 2016 - rainy day); II (sampling date November 25, 2016 - stable weather conditions)

Table 3 - Calculation of water quality index (WQI) for all sampling locations during unstable and stable weather conditions

Tablica 3 - Proračun indeksa kvalitete vode za sve lokacije uzorkovanja tijekom nestabilnih i stabilnih vremenskih uvjeta

\begin{tabular}{l|c|c}
\hline Location & WQI $_{\text {unstable }}$ & WQI $_{\text {stable }}$ \\
\hline TE Kakanj & 43.3 & 27.2 \\
\hline Čatići & 35.9 & 27.3 \\
\hline Obre & 38.3 & 28.2 \\
\hline Brežani & 39.7 & 27.4 \\
\hline Haljinići & 40.9 & 48.7 \\
\hline Kraljeva Sutjeska 1 & 38.5 & 32.1 \\
\hline Kraljevska Sutjeska 2 & 43.0 & 29.7 \\
\hline
\end{tabular}

Correlation is an effect size and we can describe the strength of the correlation using the guide ${ }^{14}$ that suggests the absolute value of Pearson's correlation factor, $r$ : 0.00 0.19 - very weak, $0.20-0.39$ - weak, $0.40-0.59$ - moderate, $0.60-0.79$ - strong, 0.80-1.0 - very strong. The parameter correlations (Pearson) in the river water from various sampling sites are reported in Tables 4 and 5 .

A very strong positive correlation among conductivity, temperature, evaporation residue, chlorides, $\mathrm{Fe}, \mathrm{Mg}, \mathrm{Mn}$, and $\mathrm{Na}$ in Trstionica river water samples during rainy day was obtained. Metals levels in water depend on the physicochemical parameters of water such as $\mathrm{pH}$, conductivity, turbidity, salinity, and total dissolved solids (TDS). It is well known that the solubility of toxic metals increases with $\mathrm{pH}$ decrease. ${ }^{15} \mathrm{~A}$ very strong correlation was calculated between $\mathrm{Ca}, \mathrm{Cu}$, and $\mathrm{Mn}$. Mn had a very strong correlation with most of the analysed parameters. A strong positive correlation indicates common source and parallel increase in their concentrations. Several authors have also reported strong positive correlation between metals for the assessment of river water quality. ${ }^{5,16,17} \mathrm{On}$ a rainy day, $\mathrm{Fe}$ and $\mathrm{Mn}$ content decreased slightly from the spring to the mouth of the Trstionica River in the Bosna River.

During stable weather conditions, a very strong positive correlation was obtained between temperature, chlorides, and Mg; Mg and evaporation residue and Cu-Fe. Generally, the lower Pearson correlation factors were obtained for samples that were collected during stable weather conditions.

Concentrations of $\mathrm{Cd}, \mathrm{Cr}, \mathrm{Ni}$, and $\mathrm{Pb}$ were low and below the limit of detection in most samples, so these metals represented no environmental threat.

\section{Conclusion}

The total dissolved metal concentrations in the selected locations along the Trstionica River reflect a certain level of anthropogenic impact on river water quality. However, based on the comparison with the $\mathrm{WHO}$ regulations, and with the world average concentrations, they can still be defined as concentrations insignificantly above the natural level. There are no previously published data about Trstionica River quality. Based on calculated WQI values, 
Table 4 - Significant parameter correlations (Pearson) in Trstionica River water samples during rainy day Tablica 4 - Značajne korelacije parametara (Pearson) u uzorcima vode rijeke Trstionice tijekom kišnog dana

\begin{tabular}{|c|c|c|c|c|c|c|c|c|c|c|c|c|}
\hline & Temperature & Conductivity & $\begin{array}{l}\text { Evaporation } \\
\text { residue }\end{array}$ & Chlorides & $\mathrm{Ca}$ & $\mathrm{Cu}$ & $\mathrm{Fe}$ & Mg & $M n$ & $\mathrm{Na}$ & $\mathrm{Pb}$ & $\mathrm{Zn}$ \\
\hline Temperature & 1 & 0.854 & 0.663 & 0.775 & 0.649 & 0.318 & 0.683 & 0.773 & 0.902 & 0.624 & 0.448 & 0.212 \\
\hline Conductivity & & 1 & 0.840 & 0.809 & 0.485 & 0.126 & 0.805 & 0.958 & 0.824 & 0,926 & 0.544 & 0.257 \\
\hline $\begin{array}{l}\text { Evaporation } \\
\text { residue }\end{array}$ & & & 1 & 0.556 & 0.243 & 0.045 & 0.690 & 0.758 & 0.706 & 0.753 & 0.694 & 0.045 \\
\hline Chloride & & & & 1 & 0.886 & 0.659 & 0.701 & 0.885 & 0.894 & 0.666 & 0.533 & 0.685 \\
\hline $\mathrm{Ca}$ & & & & & 1 & 0.894 & 0.472 & 0.577 & 0.808 & 0.247 & 0.381 & 0.717 \\
\hline $\mathrm{Cu}$ & & & & & & 1 & 0.055 & 0.272 & 0.294 & 0.063 & 0.375 & 0.683 \\
\hline $\mathrm{Fe}$ & & & & & & & 1 & 0.752 & 0.817 & 0.701 & 0.130 & 0.285 \\
\hline Mg & & & & & & & & 1 & 0.798 & 0.927 & 0.604 & 0.498 \\
\hline $\mathrm{Mn}$ & & & & & & & & & 1 & 0.580 & 0.481 & 0.402 \\
\hline $\mathrm{Na}$ & & & & & & & & & & 1 & 0.477 & 0.286 \\
\hline $\mathrm{Pb}$ & & & & & & & & & & & 1 & 0.205 \\
\hline $\mathrm{Zn}$ & & & & & & & & & & & & 1 \\
\hline
\end{tabular}

Table 5 - Significant parameter correlations (Pearson) in Trstionica River water samples during stable weather conditions Tablica 5 - Značajne korelacije parametara (Pearson) u uzorcima vode rijeke Trstionice tijekom stabilnih vremenskih uvjeta

\begin{tabular}{c|c|c|c|c|c|c|c|c|c|c}
\hline & Temperature & $\begin{array}{c}\text { Evaporation } \\
\text { residue }\end{array}$ & Chlorides & $\mathrm{Ca}$ & $\mathrm{Cu}$ & $\mathrm{Fe}$ & $\mathrm{Mg}$ & $\mathrm{Mn}$ & $\mathrm{Na}$ & $\mathrm{Zn}$ \\
\hline Temperature & 1 & 0.796 & 0.902 & 0.045 & 0.095 & 0.000 & 0.915 & 0.353 & 0.675 & 0.518 \\
\hline $\begin{array}{c}\text { Evaporation } \\
\text { residue }\end{array}$ & & 1 & 0.528 & 0.308 & 0.219 & 0.100 & 0.929 & 0.401 & 0.602 & 0.720 \\
\hline Chlorides & & & 1 & 0.195 & 0.109 & 0.173 & 0.673 & 0.409 & 0.396 & 0.257 \\
\hline $\mathrm{Ca}$ & & & & 1 & 0.241 & 0.261 & 0.077 & 0.343 & 0.095 & 0.032 \\
\hline $\mathrm{Cu}$ & & & & & 1 & 0.959 & 0.343 & 0.688 & 0.351 & 0.607 \\
\hline $\mathrm{Fe}$ & & & & & & 1 & 0.239 & 0.725 & 0.263 & 0.395 \\
\hline $\mathrm{Mg}$ & & & & & & & 1 & 0.192 & 0.773 & 0.767 \\
\hline $\mathrm{Mn}$ & & & & & & & & 1 & 0.032 & 0.161 \\
\hline $\mathrm{Na}$ & & & & & & & & 1 & 0.688 \\
\hline $\mathrm{Zn}$ & & & & & & & & 1 \\
\hline
\end{tabular}

the Trstionica River water is classified as excellent water. In order to obtain a complete status of the impact of numerous factors on the water of the Trstionica River, it would be necessary to perform passive sampling, biological, and microbiological analysis of the water, as well as continued monitoring.

\section{List of abbreviations Popis kratica}

\footnotetext{
AAS - atomic absorption spectrometry - atomska apsorpcijska spektrometrija

AES - atomic emission spectrometry - atomska emisijska spektrometrija
}

FAAS - flame atomic absorption spectrometry - plamena atomska apsorpcijska spektrometrija

LOD - limit of detection - granica detekcije

MAC - maximum allowed concentration - maksimalna dopuštena koncentracija

TDS - total dissolved solids - ukupna otopljena kruta tvar

WHO - World Health Organization - Svjetska zdravstvena organizacija

WQI - water quality index - indeks kvalitete vode 


\section{References \\ Literatura}

1. N. J. Knezović, M. Memi, M. Mabić, J. Huremović, I. Mikulić, Correlation between water hardness and cardiovascular diseases in Mostar city, Bosnia and Herzegovina, J. Water Health 12 (4) (2014) 817-823, doi: https://doi.org/10.2166/ wh.2014.129.

2. E. Nesimović, J. Huremović, S. Gojak-Salimović, N. Avdić, S. Žero, E. Nesimović, Chemical Characterisation of the Spring Waters used for Health Care, Guber, Srebrenica, Bosnia and Herzegovina, Glas. Hem. Tehnol. Bosne Herceg. 49 (2017) 43-48.

3. H. Shirkhanloo, H.Z. Mousavi, A. Rouhollahi, Preconcentration and determination of heavy metals in water, sediment and biological samples, J. Serb. Chem. Soc. 76 (11) (2011) 1583-1595, doi: https://doi.org/10.2298/JSC101024139S.

4. E. Mwashinga, Determination of Selected Heavy Metals in River Mukurumudzi to Establish Potential Contamination from Land Based Activities and Sources, Master's Thesis, Pwani University, Kenya, 2018.

5. S. K. Bhardwaj, R. Sharma, R. K. Aggarwal, Impact Appraisal of Industrialization on Heavy Metal Contamination of Sirsa River Located in the Shivalik Foothills of North Western Himalayas, Curr. World Environ. 14 (2) (2019) 245-259, doi: https://doi.org/10.12944/CWE.14.2.09.

6. K. Ahmad, A. Azizullah, S. Shama, M. N. Khan Khattak, Determination of heavy metal contents in water, sediments, and fish tissues of Shizothorax plagiostomus in river Panjkora at Lower Dir, Khyber Pakhtunkhwa, Pakistan, Environ. Monit. Assess. 186 (2014) 7357-7366, doi: https://doi. org/10.1007/s10661-014-3932-1.

7. M. De Siervi, A. F. de Iorio, C. I. Chagas, Heavy Metals in Sediments and Runoff Waters in Soils of the Matanza River Basin, Argentina, Commun. Soil. Sci. Plan. 36 (2005) 2303-
2314, doi: https://doi.org/10.1080/00103620500250742.

8. D. O. Ogoyi, C. J. Mwita, E. K. Nguu, P. M. Shiundu, Determination of Heavy Metal Content in Water, Sediment and Microalgae from Lake Victoria, East Africa, Open Environ. Eng. J. 4 (2011) 156-161.doi:10.2174/1874829501104010156.

9. W. Sabbir, M. Z. Rahman, M. M. Hasan, M. N. Khan, S. Ray, Assessment of heavy metals in river water, sediment and fish mussel in Rupsha River under Khulna District, Bangladesh, Int. J. Expt. Agric. 8 (1) (2018) 1-5.

10. A. K. Batabyal, S. Chakraborty, Hydrogeochemistry and Water Quality Index in the Assessment of Groundwater Quality for Drinking Uses, Water Environ. Res. 87 (7) (2015) 607-617, doi: https://doi.org/10.2175/106143015X1421265861395.

11. S. Bobar, Đ. Bajramović, Hemija voda, OFF-SET Tuzla, 2011.

12. World Health Organization (WHO), Geneva 2003.

13. A. Kevilj-Olovčić, A. Olovčić, J. Huremović, S. Žero, Water Quality of the Bosna River, Kem. Ind. 67 (13) (2018) P119P126, https://doi.org/10.15255/KUI.2018.018.

14. J. D. Evans, Straightforward statistics for the behavioral sciences, Pacific Grove, CA: Brooks/Cole Publishing, 1996.

15. C. Radulescu, I. D. Dulama, C. Stihi, I. Ionita, A. Chilian, C. Necula, E. D. Chelarescu, Determination of heavy metal levels in water and therapeutic mud by atomic absorption spectrometry, Rom. Journ. Phys. 59 (9-10) (2014) 1057-1066.

16. R. Y. Capangpangan, N. K. Pagapong, C. P. Pineda, P. B. Sanchez, Evaluation of potential ecological risk and contamination assessment of heavy metals in sediment samples using different environmental quality indices: a case study in Agusan river, Caraga Philippines, J. Bio. Env. Sci. 8 (2016) 1-16.

17. R. Pal, R. K. Dubey, S. K. Dubey, A. K. Singh, Assessment of heavy metal pollution through index analysis for Yamuna water in Agra region, India, Int. J. Curr. Microbiol. App. Sci. 6 (12) (2017) 1491-1498, doi: https://doi.org/10.20546/ijcmas.2017.612.166.

\section{SAŽETAK}

Kvaliteta vode rijeke Trstionice (Bosna i Hercegovina)

Šuhreta Delibašić, Jasna Huremović, Sabina Žero, and Sabina Gojak-Salimović

Ova je studija provedena kako bi se istražila kvaliteta vode rijeke Trstionice, Bosna i Hercegovina. Fizikalno-kemijska svojstva (temperatura, pH, vodljivost, ukupna kruta tvar nakon isparavanja pri $105^{\circ} \mathrm{C}$ ), sadržaj metala (Ca, Cd, Cr, Cu, Fe, Mg, Mn, Na, Ni, Pb i Zn) i aniona (kloridi i fosfati) određeni su u uzorcima vode prikupljenim na sedam lokacija tijekom dva razdoblja uzorkovanja: nestabilni vremenski uvjeti (oborine) i stabilni vremenski uvjeti (bez oborina). Došlo je do značajne razlike u sadržaju pojedinih parametara u riječnoj vodi, ovisno o vremenu uzorkovanja.

U slučaju metala, čije su koncentracije bile ispod granice detekcije primijenjene metode (FAAS), primijenjena je metoda predkoncentracije upotrebom ionsko-izmjenjivačke smole.

Koncentracije metala tijekom kišnog dana bile su u redoslijedu $\mathrm{Ca}>\mathrm{Mg}>\mathrm{Na}>\mathrm{Fe}>\mathrm{Cu}>\mathrm{Zn}>$ $>\mathrm{Pb}>\mathrm{Mn}$ sa srednjim vrijednostima 343, 6,03, 1,94, 0,18, 0,20, 0,03, 0,02, 0,01 $\mathrm{mg} \mathrm{dm}^{-3}$, odnosno za vrijeme stabilnih vremenskih uvjeta: $\mathrm{Ca}>\mathrm{Mg}>\mathrm{Na}>\mathrm{Cu}>\mathrm{Fe}>\mathrm{Mn}>\mathrm{Zn}$ sa srednjim vrijednostima od 288, 7,62, 2,38, 0,11, 0,10, 0,01, 0,01 $\mathrm{mg} \mathrm{dm}^{-3}$. Koncentracije Cd, Cr i Ni su bile ispod granice detekcije primijenjene metode u oba slučaja.

Dobivene vrijednosti uspoređene su s propisima Svjetske zdravstvene organizacije. Rezultati su pokazali da rijeka Trstionica u istraživanom dijelu toka ispunjava većinu parametara propisanih legislativom. Također su procijenjene korelacije između analiziranih parametara. Na temelju izračunatih vrijednosti indeksa kakvoće vode, Rijeka Trstionica spada u kategoriju izvrsne vode.

Ključne riječi

Rijeka Trstionica, onečišćenja, metali, AAS, kloridi, fosfati, prekoncentriranje

Sveučilište u Sarajevu, Prirodno-matematički fakultet

Zmaja od Bosne 33-35, 71000 Sarajevo

Bosna i Hercegovina
Izvorni znanstveni rad Prispjelo 20. prosinca 2019. Prihvaćeno 17. siječnja 2020. 